\title{
Antigenicity for Humans of Cow Milk Caseins, Casein Hydrolysate and Casein Hydrolysate Fractions
}

\author{
1I. NENTWICH, ${ }^{1}$ ZS. SZÉPFALUSI, ${ }^{2}$ C. KUNZ, ${ }^{3}$ P. SPUERGIN, ${ }^{1}$ R. URBANEK \\ ${ }^{1}$ Clinic of Pediatrics, University of Vienna, Vienna, Austria \\ ${ }^{2}$ Research Institute for Child Nutrition, Dortmund, Germany \\ ${ }^{3}$ University Children's Hospital, Freiburg im Breisgau, Germany
}

Received January 9, 2003

Accepted June 17, 2004

\begin{abstract}
Nentwich I., Szépfalusi Zs., Kunz C., Spuergin P., Urbanek R.: Antigenicity for Humans of Cow Milk Caseins, Casein Hydrolysate and Casein Hydrolysate Fractions. Acta Vet. Brno 2004, 73: 291-298.

Cow milk casein consists of several fractions each of which have different structure and differing antigenicity. The aim of the study was to investigate the capacity of cow milk casein, casein fractions, casein hydrolysate and its fractions to bind human IgG antibodies (antigenicity).

Whole cow milk, bovine casein, $\alpha$-casein native and dephosphorylated, $\beta$ - and $\kappa$-casein, further a casein hydrolysate and its fractions were incubated in a IgG-ELISA assay with sera from five patients with cow milk intolerance and a pooled control serum from milk drinking healthy individuals.

In healthy controls, predominantly $\beta$-caseins, both commercial and chromatographically separated, contained the strongest antigenic epitopes. In milk intolerant infants, however, $\kappa$-casein along with $\beta$-caseins was the strongest antigen. The antigenicity of the casein hydrolysate compared to nonhydrolysed casein was reduced down to 18.5 and $41.8 \%$ measured with patient and control sera, respectively. There were traces of intact protein in the hydrolysate. Antigenicity of the casein hydrolysate fractions reached only 24 to $44 \%$ of the antigenicity of the whole hydrolysate. Although their antigenicity roughly correlated with their molecular weight, only negligible differences among particular fractions were found.

Cow milk beta-casein is the strongest antigen in healthy controls while kappa-casein possesses the high antigenicity in the milk intolerant individuals. For milk intolerant individuals, the tested casein hydrolysate was approximately 5 times less antigenic compared to whole casein. Antigenicity of the hydrolysate fractions were lower than that of the whole hydrolysate. Identification of cow milk caseins and its fractions with the highest bindnig capacity for human $\mathrm{IgG}$ antibodies is important for manufacturing of antigen-reduced formulas based on casein hydrolysates.

Cow milk, caseins, infants, $\operatorname{IgG}$, protein hydrolysates
\end{abstract}

Cow milk proteins belong to the strongest antigens in human diet. Caseins, representing about $80 \%$ of all cow milk proteins (Eigel et al. 1984), have a fibrilar structure consisting of mainly sequential epitopes able to bind to specific IgG antibodies. Antigenic reactivity of a protein refers to its capacity to bind specifically to the functional binding sites or paratopes of certain immunoglobulin molecules (van Regenmortel 1988). This is different among proteins due to the manifold quality and quantity of their specific epitopes. Using heat treatment and/or enzymatic hydrolysis, a reduction of the binding capacity of the proteins can be achieved. To study antigenicity of cow milk proteins and protein fragments sera from immunized animals on one hand and from sensitized human individuals on the other hand, can be used (Otani 1989; Otani et al. 1989). Comparing antigenicity of casein hydrolysate to that of raw casein gives information on the efficacy of hydrolysis performed. Assessment

\footnotetext{
Address for correspondence:

MUDr. Ivo Nentwich, Ph.D

c/o Prof. MUDr. J. Lokaj, CSc.

Institute of Clinical Immunology and Allergology

Faculty of Medicine, Masaryk University Brno

Pekařská 53, CZ-656 91 Brno, Czech Republic
}

\author{
Phone: + 420543183126 \\ Fax: + 420543183143 \\ E-mail: nentwich@volny.cz \\ http://www.vfu.cz/acta-vet/actavet.htm
}


of antigenicity of particular casein hydrolysate fractions indicates the extent of hydrolysis necessary for efficient antigenicity reduction of the hydrolysate.

In the present study we investigated the antigenicity of cow milk caseins: whole casein, $\alpha$-casein, $\alpha$-casein after dephosphorylation, $\beta$ - and $\kappa$-casein. The difference in antigenicity between casein hydrolysate, whole cow milk and intact casein was further evaluated. Finally, residual antigenicity of casein hydrolysate peptide fractions together with their molecular weights were assessed.

Patient and control sera

\section{Materials and Methods}

Sera from 5 patients (4 children, 1 adult) sufferring from adverse reactions to cow milk (vomiting, diarrhea, abdominal colic, skin symptoms) were used. A sample of venous blood was drawn from each patient and let clot. After centifugation, the serum was sampled and frozen at $-20{ }^{\circ} \mathrm{C}$ until analysis. The sera were analysed within 2 months from sampling.

\section{Controls}

The same procedure was applied to obtain control sera. As controls, 4 adult individuals regularly drinking cow milk and showing no symptoms of milk intolerance were used. The sera were fused together to obtain a pooled control serum.

\section{Antigens}

An overview of antigens tested is given in Table 1.

Table 1: Overview of the cow milk antigens tested

\begin{tabular}{|l|l|l|}
\hline Designation & content & Source \\
\hline cow milk & Protein mixture & dairy \\
\hline whole casein & Protein mixture & Sigma \\
\hline b-casein-S & casein fraction & Sigma \\
\hline $\begin{array}{l}\text { a-casein } \\
\text { a-casein dephosphorylated (=ad-casein) }\end{array}$ & casein fractions & $\begin{array}{l}\text { Affinity chromatography } \\
\text { from commercial casein } \\
\text { (Sigma) }\end{array}$ \\
k-casein & & \\
\hline $\begin{array}{l}\text { casein hydrolysate } \\
\text { (pPLC-fractions of casein hydrolysate } \\
(1-9)\end{array}$ & $\begin{array}{l}\text { protein/peptide mixture } \\
\text { of an antigen-reduced infant } \\
\text { formula) }\end{array}$ & Milupa \\
\hline
\end{tabular}

Abbreviations:

ELISA enzyme-linked immunosorbent assay

FPLC fast protein liquid chromatography

Fresh non-heated low-fat cow milk was obtained from a dairy. Cow milk was defatted three times by centrifugation for 10 minutes at $300 \mathrm{~g}$. The whole casein from cow milk was purchased from Sigma (St. Louis, USA) as well as the $\beta$-casein designed as B-casein-S (Sigma). The whole casein, casein hydrolysate as well as all casein fractions were not pretreated.

Isolation of other casein fractions ( $\alpha$-casein, $\alpha$-casein dephosphorylated, $\beta$-casein and $\kappa$-casein) is decribed elsewhere (Spuergin et al. 1996; Spuergin et al. 1997). Briefly, the commercially available bovine casein (C7891, Sigma) was purified by anion exchange chromatography by means of the High-Load System (Pharmacia). An amount of $300 \mathrm{mg}$ casein was dissolved in $4.0 \mathrm{ml}$ of buffer A (Tris/HCl $20 \mathrm{mmol} / \mathrm{l}, \mathrm{pH} 7.0 ; 4 \mathrm{~mol} / \mathrm{l}$ urea and 10 $\mathrm{mmol} / \mathrm{l}$ 2-mercaptoethanol) and applied onto a Sepharose FastFlow column equilibrated with the same buffer. Caseins were eluted at a flow rate of $1.0 \mathrm{ml} / \mathrm{min}$ with a gradient of $0-350 \mathrm{mmol} \mathrm{NaCl}$ in buffer $\mathrm{A}$ in $100 \mathrm{~min}$, 
followed by a 20-min wash with $350 \mathrm{mmol} \mathrm{NaCl}$, a second gradient of 350-500 mmol NaCl in 10 min and a final 20-min wash with $500 \mathrm{mmol} \mathrm{NaCl}$. Eluted proteins were detected by absorption at $280 \mathrm{~nm}$ (Uvicord SII, Pharmacia). Pooled fractions were desalted and lyophilized. The purity and identitiy of caseins were checked by SDS-PAGE and by N-terminal amino-acid sequencing with a gas-phase sequencer (Protein Sequencer, Applied Biosystems).

The casein hydrolysate was kindly supplied by Milupa AG (Fridrichsdorf, Germany). It is used as the protein/peptid component of various hypoantigenic infant formulas. The method of manufacturing casein hydrolysate is not known to us as it is a subject of commercial secret. All substances were stored at $-20^{\circ} \mathrm{C}$.

\section{Casein hydrolysate separation}

The casein hydrolysate fractions were obtained by separation and isolation of the casein hydrolysate according to their molecular weights by fast protein liquid chromatography (FPLC system; Pharmacia Freiburg, Germany), in connection with a gel permeation column (Superdex 75 HR 10/30; Pharmacia Freiburg, Germany). The casein hydrolysate was dissolved $(10 \mathrm{mg} / \mathrm{ml})$ in deionized water, filtered and $100 \mu \mathrm{l}(1000 \mu \mathrm{g})$ was run through the column, then eluted with Tris- $\mathrm{NaCl}$ buffer (Tris- $\mathrm{HCl} 10 \mathrm{mM}$; NaCl $100 \mathrm{mM}$; SDS 0.1\%; pH 6.8). The UV absorption was continually measured at $280 \mathrm{~nm}$. The fractions were collected, freeze-dried and stored at $-20{ }^{\circ} \mathrm{C}$. The FPLCanalyses were carried out in the Research Institute for Child Nutrition, Dortmund, Germany.

\section{ELISA IgG-binding assay}

A modification of a standard method (Firer et al. 1981) was used. ELISA high affinity plates (Greiner, Kremsmünster, Austria) were pretreated with $5 \%$ v/v glutaraldehyde/carbonate buffer $\left(\mathrm{Na}_{2} \mathrm{CO}_{3} 15 \mathrm{mM} ; \mathrm{NaHCO}_{3}\right.$ $35 \mathrm{mM} ; \mathrm{pH} 9.5)$ solution for three hours. The respective antigens in the quantity of $4 \mu \mathrm{g}(100 \mu \mathrm{lof} 40 \mu \mathrm{g} / \mathrm{ml}$ dilution $)$ of protein/peptide equivalent, were dissolved in the same carbonate buffer and incubated at $4{ }^{\circ} \mathrm{C}$ overnight. After washing with Tris buffered saline (TBS) (Tris- $\mathrm{HCl} 50 \mathrm{mM}$; NaCl $150 \mathrm{mM}$; Tween 20: 0.5\%; pH 7.5) blocking of unspecific binding sites with $1 \%$ human serum albumin (HSA) (Behring, Germany) in TBS (HSA-TBS) was performed for $1 \mathrm{~h}$. Test sera diluted 1:400 (1:200) in HSA-TBS were incubated at $4{ }^{\circ} \mathrm{C}$ overnight. As higher concentration of antibodies is necessary to bind to peptides, for assays with casein hydrolysate peptide fractions, only sera of milk intolerant patients were used and these were diluted 1:200. After washing, incubation with 1:2000 in HSA-TBS diluted alkaline phosphatase-labelled goat anti-human IgG antibody (ACCU-SPECS, Westbury, NY, USA), was performed for $2 \mathrm{~h}$. Final IgG binding was visualized with p-nitrophenyl phosphate (St. Louis, USA). The enzymatic reaction was stopped by adding $200 \mathrm{mM}$ hydrochloric acid after $20 \mathrm{~min}$ and the absorbance was measured at $405 \mathrm{~nm}$ with an ELISA reader.

\section{Results}

\section{Antigenicity of casein and casein fractions}

The average binding capacity of the patient sera to various cow milk antigens compared to the pooled serum of asymptomatic individuals is shown in Fig. 1.

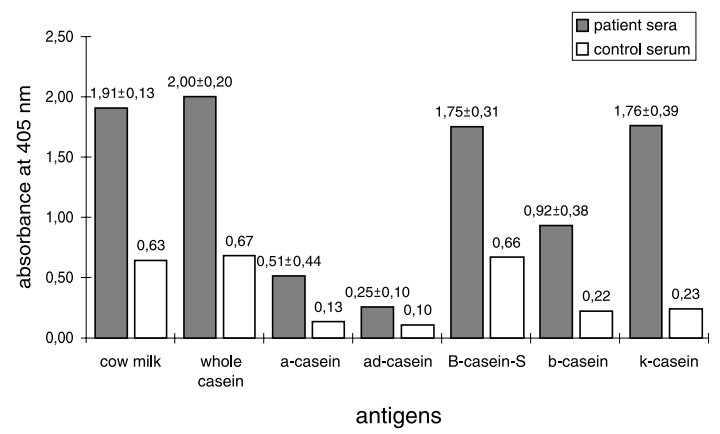

Fig. 1. IgG binding capacity of cow milk caseins compared to cow milk (absorbance values of the respective patient and control sera mean \pm standard deviation are given at 1:400 sera dilution). B-casein-S: $\beta$-casein from Sigma; b-casein: affinity chromatography separated $\beta$-casein-fraction.

The high binding capacity of cow milk is probably due to the relatively high content of caseins. Casein possesses even higher antigenicity than the corresponding amount of whole cow milk. The strongest difference in binding capacity between the test sera and standard serum was seen in $\kappa$-casein (approx. 8-fold rise); it was also the most antigenic fraction out 
of all casein fractions. There was a substantial difference between the industrially separated $90 \%$ pure $\beta$-casein (B-casein-S) and the $\beta$-casein (b-casein) separated with anion exchange chromatography. This could be explained by the possible presence of another casein fraction with a higher antigenicity. Furthermore a reduced $\mathrm{IgG}$ binding of dephosphorylated $\alpha$-casein compared to native $\alpha$-casein was found.

Antigenicity of the casein hydrolysate and its peptide fractions

The IgG binding capacity of the whole casein hydrolysate compared to those of cow milk and the whole casein is demonstrated in Fig. 2.

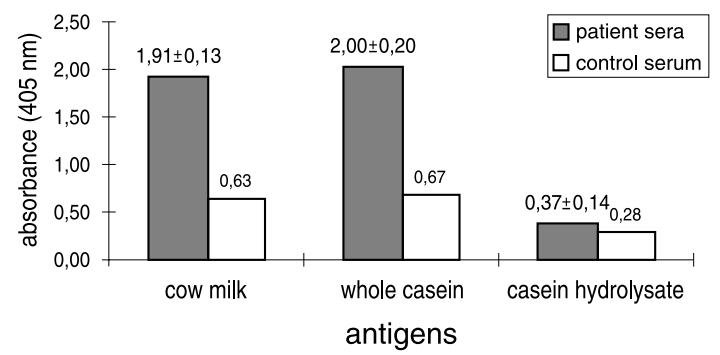

Fig. 2. IgG binding capacity of the casein hydrolysate compared to cow milk and the whole casein (absorbance values of the respective test sera mean \pm standard deviation are given at 1:400 sera dilution).

A strong antigenicity was seen in cow milk and the whole casein (more than 3 fold to control serum; for casein: optical density 2.00 in patient sera versus 0.67 in control sera). The casein hydrolysate shows only about $18.5 \%$ of casein antigenicity (optical density 0.37 versus 2.00). Almost no difference was seen between patient and control sera in casein hydrolysate IgG binding.

The results of the liquid chromatographic analysis of the casein hydrolysate and the IgG binding capacity of the casein hydrolysate fragments with known molecular weight are shown in Figs 3 and 4, respectively.

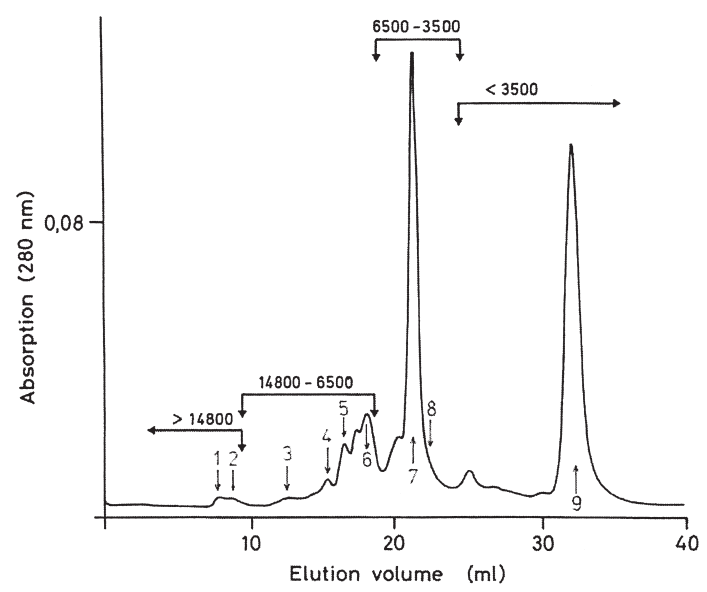

Fig. 3. FPLC gel permeation chromatogram of casein hydrolysate (Superdex 75 HR 10/39 Pharmacia, Tris-NaCl buffer $\mathrm{pH}$ 6.8). The arrows on the top point the respective molecular weight ranges in $\mathrm{Da}$ and the numbers at the bottom indicate the particular fractions collected and tested. Molecular weight ranges were determined on the basis of standard proteins. 


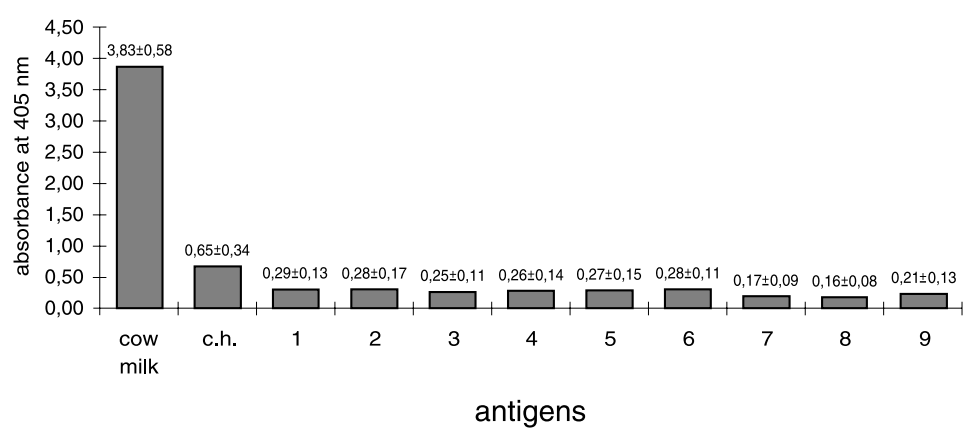

Fig. 4. IgG binding capacity of casein hydrolysate fractions of diverse molecular weights compared to those of casein hydrolysate and cow milk (absorbance values of the respective test sera mean \pm standard deviation are given at 1:200 sera dilution, the value for cow milk was calculated by extrapolation). The numbers of each fraction refer to the FPLC-chromatogram.

Considering the molecular weight pattern of the investigated hydrolysate, $99 \%$ of the peptide fragments have a molecular weight lower than $9.2 \mathrm{kDa}$ and more than $80 \%$ lower than $8.4 \mathrm{kDa}$. The antigenicity of particular fractions ranged from $44.6 \%$ (fraction 1) down to $24.6 \%$ (fraction 8 ) of the binding capacity of the whole casein hydrolysate. None of the fractions reached the antigenicity value of the whole casein hydrolysate.

\section{Discussion}

Cow milk is a mixture of proteins, about $80 \%$ of which are caseins. Caseins from cow milk form an inhomogenous group of proteins with fibrilar structure consisting of 4 major fractions: $\alpha_{\mathrm{s} 1^{-}}, \alpha_{\mathrm{s} 2}$-caseins, $\beta$ - and $\kappa$ - each forming about 45, 10, 34 and $11 \%$ of the whole casein amount respectively (Alais and Blanc 1975)

Production of anti-cow milk IgG antibodies represents a normal response of an organism to cow milk antigens and is dependent on the diet (Kemeny et al. 1991; Less of et al. 1991). After an initial peak in the generation of milk specific IgG, these levels remain relatively stable after the 9th month of age in individuals with milk diet (Tainio et al. 1988; Müller 1988). However, its level is markedly increased in some pathological conditions like inflammatory bowel disease, coeliac disease, cow milk sensitive enteropathy (Firer et al. 1987; Lerner et al. 1989) and also eczema (Firer et al. 1982).

The investigated sera recognized most of the antigenic sites of bovine $\kappa$-casein. The epitope structure of this casein fraction has been reported to differ significantly from those of human K-casein (Otani et al. 1991). Thus, it represents one of the strongest immunogens in bovine milk. On the contrary, bovine $\beta$-casein was found to have a sequence homology of $47 \%$ with human $\beta$-casein (Otani et al. 1988). This antigenic similarity might, to some extent, explain the reduced binding capacity for human $\operatorname{IgG}$ antibodies.

As reported by Heine et al. (1989), processing milk proteins by desialization and/or dephosphorylation changes their immunologic properties. Thus, a decreased IgG binding of dephosphorylated $\alpha$-casein confirms not only the reduction of antigen binding capacity, but also suggests a decline of antigenicity.

Mind the difference in antigenicity of particular casein fractions between sera of healthy controls and those of patients with cow milk intolerance. The sera of healthy controls 
recognized mostly epitopes in B-casein-S, and to a lesser extent those of $\kappa$-casein and $\beta$-casein. Interestingly, milk intolerant infants generated IgG-antibodies mostly to $\kappa$-casein and B-casein-S. It may be thinkable that $\kappa$-casein be differently processed by antigen presentation cells and presented to immunocompetent cells in the gut associated lymphatic tissue of milk intolerant infants. This may lead to enhanced systemic production of specific IgG antibodies to this casein fraction. The difference between antigenicity of commercial B-casein-S (Sigma) and that of chromatographically purified $\beta$-casein may have arisen due to different isolation process of this fraction from whole casein.

The procedures to reduce the antigenicity of milk proteins are heat treatment, which reduces the amount of conformational epitopes in globular proteins, and enzymatic hydrolysis, where cleavage of the protein's primary structure occurs (Lee 1992). The antigenicity (Fallstrom et al. 1986; Gortler and Urbanek 1990; Leary, Jr. 1992; Wahn et al. 1992) and immunogenicity (Stephan et al. 1990; Cordle et al. 1991) of protein hydrolysates and milk proteins (Wahn et al. 1981) have recently been studied in animal and human models. These studies demonstrated a decreasing antigenicity with the increasing degree of hydrolysis due to the reduction of epitopes. Moreover, peptides from hydrolysed milk show both reduced immunogenicity (Cordle et al. 1991) and seem to induce oral tolerance without elicitating antibody response (Enomoto et al. 1993). However, despite of excessive hydrolysis, intact cow milk proteins may persist in hypoantigenic formulae mostly in low degree hydrolysates (Makinen-Kiljunen and Sorva 1993) and elicit severe clinical reactions in highly sensitized individuals (E1lis et al. 1991; Saylor and Bahna 1991).

Although there is a solid evidence on the usefulness of hydrolysate formulae, it is not known by now, what degree of hydrolysis is necessary to obtain the desired reduction of antigenicity and what peptide fractions are responsible for the residual antigenicity of the hydrolysate.

The antigenicity of whole casein hydrolysate represented about $18 \%$ of that of cow milk. As there are only traces of fragments with a molecular weight higher than $10 \mathrm{kDa}$ present in the investigated hydrolysate, the hydrolysate can be labelled as partially hydrolysed with relative high residual antigenicity.

The molecular weight of the FPLC-fraction with the highest antigenicity (fraction 1) ranged over $14.8 \mathrm{kDa}$. However, from the quantitative point of view, it represents a very small fraction. On the other hand, the peptide fraction with the lowest antigenicity belonged to the $6.5-3.5 \mathrm{kDa}$ range. As we used peptides to recognize the antibody generated by the entire protein molecule, it can be assumed that if these fragments bind to the IgG protein antibodies, they probably contain epitopes of the whole protein. The smallest peptide that still possesses some residual antigenic reactivity represents the epitope; in general it corresponds to a size of 5-7 amino acid residues (Regen mortel van 1988). The differences in antigenicity between particular hydrolysate fractions were negligible and none of the fractions reached the antigenicity of the whole casein hydrolysate. This can be partly explained by altered aggregation and immunologic behaviour of peptides in the entire hydrolysate mixture tending to form macromolecular complexes.

In infants with high risk of developing an atopic disease, preventive measures such as dietary prophylaxis with breast feeding or hydrolysed formulae are recommended. Milk processing as the enzymatic hydrolysis of casein does reduce the capacity of casein peptides to bind to specific antibodies. The identification of hydrolysate fractions with highest antigenicity by specific antibody binding assays appears to be a useful tool for in vitro characterization of cow milk hydrolysates. 


\section{Antigenicita kaseinů kravského mléka, kaseinového hydrolyzátu a frakcí kaseinového hydrolyzátu}

Kasein kravského mléka obsahuje několik frakcí. Každá z nich má různou strukturu a různou antigenicitu. Cílem práce bylo stanovit vazebnou kapacitu kaseinu kravského mléka, kaseinových fakcí, kaseinového hydrolyzátu a jeho peptidových frakcí pro lidské protilátky třídy IgG (antigenicitu).

Nativní kravské mléko, bovinní kasein, $\alpha$-kasein nativní i defosforylovaný, $\beta$ - a $\kappa$-kasein, dále kaseinový hydrolyzát a jeho frakce byly inkubovány se séry 5 pacientů trpících intolerancí kravského mléka a se sebraným kontrolním sérem od zdravých jedinců pijících kravské mléko. Vazba protilátek třídy IgG byla vyšetřena metodou ELISA.

U zdravých kontrol měly nejvyšší antigenicitu $\beta$-kaseiny (komerční i chromatograficky izolovaný). U jedinců s intolerancí kravského mléka byly nejsilnějšími antigeny $\kappa$-kasein současně s $\beta$-kaseiny. Antigenicita kaseinového hydrolyzátu ve srovnání s nehydrolyzovaným kaseinem byla snížena na 18,5 \% u pacientů a na 41,8\% u zdravých kontrol. V hydrolyzátu byly chromatograficky nalezeny stopy intaktních bílkovin. Antigenicita jednotlivých frakcí kaseinového hydrolyzátu dosahovala od $24 \%$ do $44 \%$ antigenicity celého hydrolyzátu. Ačkoliv antigenicita frakcí přibližně korelovala s jejich molekulovou hmotností, rozdíly v antigenicitě mezi jednotlivými frakcemi byly zanedbatelné.

Beta-kasein byl nejsilnějším antigenem u zdravých kontrol, zatímco kapa-kasein představuje silný antigen u jedinců s intolerancí kravského mléka. Kaseinový hydrolyzát je pro pacienty s intolerancí kravského mléka přibližně pětkrát méně antigenní ve srovnání s nehydrolyzovaným kaseinem. Antigenicita hydrolyzátových frakcí byla nižší než antigenicita celého hydrolyzátu. Identifikace kaseinů a jejich frakcí s nejvyšší vazebnou kapacitou pro lidské protilátky třídy IgG je důležitá pro výrobu kojeneckých mléčných přípravků se sníženou antigenicitou založených na kaseinových hydrolyzátech.

\section{References}

ALAIS, C, BLANC, B 1975: Milk proteins: Biochemical and biological aspects. World review of nutrition and dietetics. Karger, Basel, pp. 66-167.

CORDLE, CT, MAHMOUD, MI, MOORE, V 1991: Immunogenicity evaluation of protein hydrolysates for hypoallergenic infant formulae. J Pediatr Gastroenterol Nutr 13: 270-276

EIGEL, WN, BUTLER, JE, ERNSTROM, CA, FARRELL, HMJR, HARWALKAR, VR, JENNESS, R, WHITNEY, RMCL 1984: Nomenclature of proteins of cow's milk: Fifth revision. J Dairy Sci 67: 1599-1631

ELLIS, MH, SHORT, JA, HEINER, DC 1991: Anaphylaxis after ingestion of a recently introduced hydrolyzed whey protein formula. J Pediatr 118: 74-77

ENOMOTO, A, KONISHI, M, HACHIMURA, S, KAMINOGAWA, S 1993: Milk whey protein fed as a constituent of the diet induced both oral tolerance and a systemic humoral response, while heat-denatured whey protein induced only oral tolerance. Clin Immunol Immunopathol 66: 136-142

FALLSTROM, SP, AHLSTEDT, S, CARLSSON, B, LONNERDAL, B, HANSON, LA 1986: Serum antibodies against native, processed and digested cow's milk proteins in children with cow's milk protein intolerance. Clin Allergy 16: 417-423

FIRER, MA, HOSKING, CS, HILL, DJ 1981: Milk-specific antibody measurement by elisa: development of an assay. J Immunol Methods 46: 31-40

FIRER,MA, HOSKING, CS, HILL, DJ 1982: Cow's milk allergy and eczema: patterns of the antibody response to cow's milk in allergic skin disease. Clin Allergy 12: 385-390

FIRER, MA, HOSKINGS, CS, HILL, DJ 1987: Humoral immune response to cow's milk in children with cow's milk allergy. Relationship to the time of clinical response to cow's milk challenge. Int Arch Allergy Appl Immunol 84: 173-177

GORTLER, I, URBANEK, R 1990: [Antigenicity and allergenicity of hypoallergenic hydrolysate for infant nutrition]. Monatsschr Kinderheilkd 138: 605-610

HEINE, W, WUTZKE, KD, RADKE, M 1989: [Decreasing the immunogenicity of milk proteins by desialinization]. Infusionstherapie 16: 264-266

KEMENY, DM, PRICE, JF, RICHARDSON, V, RICHARDS, D, LESSOF, MH 1991: The IgE and IgG subclass antibody response to foods in babies during the first year of life and their relationship to feeding regimen and the development of food allergy. J Allergy Clin Immunol 87: 920-929 
LEARY, HL, Jr. 1992: Nonclinical testing of formulas containing hydrolyzed milk protein. J Pediatr 121: S42-S46

LEE, YH 1992: Food-processing approaches to altering allergenic potential of milk- based formula. J Pediatr 121: S47-S50

LERNER, A, ROSSI, TM, PARK, B, ALBINI, B, LEBENTHAL, E 1989: Serum antibodies to cow's milk proteins in pediatric inflammatory bowel disease: Crohn's disease vs. ulcerative colitis. Acta Paediatr Scand 78: 81-86

LESSOF, MH, KEMENY, DM, PRICE, JF 1991: IgG antibodies to food in health and disease. Allergy Proc 12: 305-307

MAKINEN-KILJUNEN, S, SORVA, R 1993: Bovine beta-lactoglobulin levels in hydrolysed protein formulas for infant feeding. Clin Exp Allergy 23: 287-291

MÜLLER, W 1988: Milchantikörper im Kindesalter. Thieme Verlag, Stuttgart, New York, 57-58 p.

OTANI, H 1989: Human serum antibodies to cow milk proteins in infants and children having clinical allergic symptoms. Milchwissenschaft 44: 131-133

OTANI, H, DONG, XY, HARA, T, KOYOBASHI, M, KAYAHARA, H, HOSONO, A 1989: Specificities to cow milk proteins of human serum antibodies from clinically allergic patients. Milchwissenschaft 44: 267-270

OTANI, H, MINE, Y, HOSONO, A 1988: The common antigenic site of bovine and human $\beta$-caseins. Milchwissenschaft 43: 705-707

OTANI, H, NEGORO, H, HOSONO, A 1991: Studies on the antigenicity of cow $\kappa$-casein. Milchwissenschaft 46: 23-26

REGENMORTEL VAN, MHV 1988: Molecular dissection of protein antigens and the prediction of epitopes. In: Regenmortel van MHV, Briand JP, Muller S, Plaué S (Ed).: Synthetic polypeptides as antigens. Elsevier, Amsterdam, New York, Oxford, pp. 9.

SAYLOR, JD, BAHNA, SL 1991: Anaphylaxis to casein hydrolysate formula. J Pediatr 118: 71-74

SPUERGIN, P, MUELLER, H, WALTER, M, SCHILTZ, E, FORSTER, J 1996: Allergenic epitopes of bovine alpha S1-casein recognized by human IgE and IgG. Allergy 51: 306-312

SPUERGIN, P, WALTER, M, SCHILTZ, E, DEICHMANN, K, FORSTER, J, MUELLER, H 1997: Allergenicity of alpha-caseins from cow, sheep, and goat. Allergy 52: 293-298

STEPHAN, V, KUHR, J, SAWATZKI, G, URBANEK, R 1990: [The immunogenicity and allergenicity of an experimental cow's milk protein hydrolysate]. Z Ernahrungswiss 29: 112-121

TAINIO, VM, SAVILAHTI, E, ARJOMAA, P, SALMENPERA, L, PERHEENTUPA, J, SIIMES, MA 1988: Plasma antibodies to cow's milk are increased by early weaning and consumption of unmodified milk, but production of plasma IgA and IgM cow's milk antibodies is stimulated even during exclusive breast- feeding. Acta Paediatr Scand 77: 807-811

WAHN, U, PETERS, T, Jr., SIRAGANIAN, RP 1981: Allergenic and antigenic properties of bovine serum albumin. Mol Immunol 18: 19-28

WAHN, U, WAHL, R, RUGO, E 1992: Comparison of the residual allergenic activity of six different hydrolyzed protein formulas. J Pediatr 121: S80-S84 